PRINT ISSN 1119-8362

Electronic ISSN 1119-8362
Full-text Available Online at https://www.ajol.info/index.php/jasem

http://ww.bioline.org.br/ja
J. Appl. Sci. Environ. Manage.

Vol. 25 (5) 867-870 May 2021

\title{
Antibiogram Screening of Edible oils Sold in two Geopolitical Zones of Nigeria
}

\author{
*AKOMAH-ABADAIKE, ON; IWUJI, OB
}

\author{
University of Port Harcourt, School of Science laboratory Technology, Microbiology Technology Option PMB 5323 Choba, Port Harcourt \\ Rivers State, Nigeria \\ *Corresponding Author Email: onyinyechi.akomah@yahoo.com; onyinyechi.akomah@uniport.edu.ng
}

\begin{abstract}
Edible oil is of the most important and widely used processed foods. The study was carried out to assess the microbiological quality of edible oil (Shea butter, Coconut oil and Palm Kernel oil) from two geopolitical zones of the country. A total of thirty (30) samples were gotten from four (4) different markets in the two geopolitical zones. Bacteria and Fungi were isolated and identified base on cultural, microscopic, biochemical characteristics and antibiotic sensitivity test were carried out. The total heterotrophic bacteria count (THBC) of the sample ranged from $3.1 \times 10^{3}-3.6 \times 10^{4}$ $\mathrm{cfu} / \mathrm{ml}$. The total heterotrophic fungi count ranged from $1.0 \times 10^{2}-6.4 \times 10^{3} \mathrm{cfu} / \mathrm{ml}$. The bacteria isolated and identified were Bacillus sp., Escherichia sp., Pseudomonas sp., Micrococcus sp., Staphyloccus sp., Enterobacterium sp., and Klebsiella sp while the fungi were Aspergillus niger, Aspergillus fumigatus, Rhizopus, Fusarium, Candida sp and Penicillium sp. The antibiogram of the Gram positive bacteria showed that all the organisms were sensitive to Erythromycin $(100 \%)$ while Gram negative organisms were sensitive to Ofloxacin (100\%) and Ciprofloxacin $(100 \%)$. The bacterial load of all the samples fell within the minimum acceptable range according to CODEX standard. It is important that improve aseptic techniques be employed in the production, handling and marketing of edible oil.
\end{abstract}

\section{DOI:https://dx.doi.org/10.4314/jasem.v25i5.28}

Copyright: Copyright $\odot 2021$ Akomah-Abadaike and Iwuji. This is an open access article distributed under the Creative Commons Attribution License (CCL), which permits unrestricted use, distribution, and reproduction in any medium, provided the original work is properly cited.

Dates: Received: 20 March 2021; Revised: 21 April 2021; Accepted: 28 April 2021

Keywords: Edible oil, Antibiogram, Ofloxacin, Candida, Staphyloccus

There are lot of natural resources in Nigeria such as the oil palm tree (Elaeis guineensis), Shea tree (Vitellaria paradoxa) and Coconut tree (Cocos nucifera linn) from which edible oil can be extracted (Macaire et al., 2010). Edible oil is a fatty liquid that is physically extracted from plant, animal tissues and also microorganisms (Bukola and Onilude, 2017). Palm kernel oil is extracted from the nut of oil palm tree, Shea butter from Shea tree and coconut oil from coconut tree respectively. Edible oil is not only an essential nutrient and flavouring for people, but also an important raw material for chemical and medical industries. Edible oils continue to be in high demand because they are preferred as healthy diets as well as raw materials for industrial products such as cosmetics and biofuel (Mercy and Johannes, 2017). The fat from the shea nuts, palm kernel, and coconut have been used significantly in applications such as soaps and detergents production, cosmetics, and illuminants for the local industries in the tropical regions of Africa.
They have also been used widely in many food products. Due to their unique properties and economic importance they are perceived to play a significant role in poverty alleviation and food security in tropical Africa, as well as valued export commodities (Sharafi et al., 2015). There are several fats and oils available from animal, vegetable and marine sources, but there are no other oils except coconut oil, palm kernel oil, babassu oil and cohune oil which contain medium chain fatty acid (C8 - C12) in significant amount (Babayan, 1987). The medium chain fatty acids have some functional and nutritional properties which include antiviral, antibacterial, antiplaque, antiprotozoal, anti-inflammatory and anti-obesity effects (Gopala, et al., 2010, German and Dillard, 2004). These properties distinguish coconut oil and palm kernel oil. In Nigeria traditional methods of productions are employed for the extraction of edible oils by individuals who have little or no knowledge neither of modern aseptic production techniques nor of 
the microbiological implication of poor sanitation and storage methods (Waktole, 2018). Microorganisms are known to cause chemical changes in edible oil leading to deterioration in the quality of their physical and chemical compositions (Okehalu et al., 2011). The aim of the study is to assess the microbial load and physico-chemical characteristic of some edible oil sold in two geopolitical zones (South-South and South-East) of the country and to determine the quality of oil used daily by the larger part of the zone. The objectives of the study is to. (1) Determine the microbial quality of the edible oil samples (2) Analyze the quality of the sample through the pathogenic organisms identified and the potential to cause harm to human. (3) Determine the antibiogram on the different organisms isolated.

\section{MATERIALS AND METHODS}

Collection of sample: The samples of edible oil, (Shea butter, coconut and palm kernel oil) were obtained from different markets; Oba market, mile one market (both representing South-south region), Ekitiafor and New markets (representing South-East region). The samples were transported aseptically to the laboratory for analysis. The samples were designated as follows; Shea butter (SBO1, SBO2, SBM1,SBM2, SBE1, SBE2, SBN1,SBN2, SBB, SBB), Coconut oil (COO1,COO2, COM1,COM2, COE1, COE2, CON1, CON2, COB, COB) Palm kernel (PKO1, PKO2, PKM1, PKM2, PKE1, PKE2, PKN1, PKN2, PKB, PKB).

Microbiological evaluation of the samples: The method described by Cheesbrough, (2005) was adapted. About $0.1 \mathrm{ml}$ of the sample from dilution $10^{-1}$ and $10^{-2}$ were plated on Nutrient agar (NA) plates for the enumeration of total heterotrophic bacteria, Salmonella Shigella agar (SSA) to isolate Salmonella and Shigella sp and MacConkey agar to determine the presence of coliform using spread plate method and Potato dextrose agar for enumeration of total heterotrophic fungi. The inoculated bacteria plates were incubated at $37^{\circ} \mathrm{C}$ for $18-24$ hours while the fungi plates at $28^{\circ} \mathrm{C}$ for $5-7$ days. Bacteria were identified using cultural and morphological characteristics, Gram staining, motility test and biochemical reactions (Methylred-Voges Proskauers (MRVP) test, sugar fermentation tests, catalase, indole, production test, test for hydrogen sulphide and gas production, citrate utilization test, urease test, etc.

Antibiotic susceptibility test: The antibiotic sensitivity pattern of the isolates was determined using the disc diffusion method (Harley and Prescott, 2005). Mueller Hinton agar plates were prepared and appropriately labelled. The plates were seeded with the standardized bacterial cultures (0.5 McFarland) by spread plate technique. The inoculated plates were left to dry for 15 minutes. Commercially available antibiotics disc containing varying concentration of various types of antibiotics were placed at adequate distances on each of the seeded agar plates with the aid of sterile forceps under aseptic conditions. The antibiotics disc were;

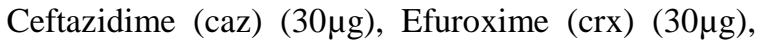

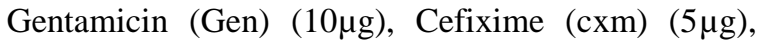
Ofloxacin (ofl) $(5 \mu \mathrm{g})$, Augmentin (aug) (30 $\mu \mathrm{g}$ ), Nitrofurantin (Nit) $(300 \mu \mathrm{g})$ and Ciprofloxacin (cpr) $(5 \mu \mathrm{g})$. The plates were incubated for 24 hours at $37^{\circ} \mathrm{C}$. The resultant visible zones of inhibition were measured in millimeters ( $\mathrm{mm}$ ). Distance lesser than 14 $\mathrm{mm}$ were regarded as resistant $(\mathrm{R})$ while distance that ranged from $14 \mathrm{~mm}$ to $17 \mathrm{~mm}$ were indicated as intermediate (I). Also, zones of inhibition greater than $17 \mathrm{~mm}$ were recorded as susceptible (S)

\section{RESULTS AND DISCUSSION}

The total heterotrophic bacteria (THB) count of the edible oil samples are shown in table 1. Unbranded Shea butter recorded THB count of $1.02 \times 10^{4}$ $3.16 \times 10^{4} \mathrm{cfu} / \mathrm{ml}$, unbranded coconut oil $3.0 \times 10^{3}-$ $1.38 \times 10^{4} \mathrm{cfu} / \mathrm{ml}$, palm kernel oil $3.1 \times 10^{3}-4.7 \times 10^{3}$ $\mathrm{cfu} / \mathrm{ml}$. Branded Shea butter and branded coconut oil samples recorded nil microbial load. Coconut oil and palm kernel samples have microbial load below the permissible limit of not more than two in a $10^{-4} \mathrm{ml}$ dilution (Yusuf et al., 2017).

Some Shea butter samples recorded microbial load above the permissible limit. Statistically there were no significant different at $p \geq 0.05$ between means of THB of the different edible oil samples and of different geographical regions. Total coliform count were carried out as hygiene indicator. Shea butter samples have coliform count ranged from $2.2 \times 10^{2}-8.5 \times 10^{2}$, coconut oil $1.1 \times 10^{2}-6.4 \times 10^{2}$ and palm kernel oil nil to $1.1 \times 10^{3}$. All samples have coliform count above the permissible level $1.4 \log _{10}$. (Codex Alimentarius, 1992).No visible growth of coliform was observed in branded samples of Shea butter and coconut oil. The coliform count has Shea butter $>$ coconout oil $>$ palm kernel oil. Coconut oil and Palm kernel oil samples recorded no count for Salmonella and Shigella while Shea butter samples recorded few count for Salmonella and Shigella (Table 2), this is similar to finding of Akomah-Abadaike and Sulaiman, (2019, Waktole et al (2018). 
Table 1: Total heterotrophic mean bacterial count

\begin{tabular}{lllllll}
\hline \multirow{2}{*}{ Markets } & \multicolumn{2}{l}{ Shea butter } & \multicolumn{2}{l}{ Coconut oil } & \multicolumn{2}{l}{ Palm kernel } \\
\cline { 2 - 7 } & Cfu/ml & Logcfu/ml & Cfu/ml & Logcfu/ml & Cfúml & Logcfu/ml \\
\hline Oba market & $1.03 \times 10^{4}$ & 4.01 & $1.02 \times 10^{4}$ & 4.01 & $3.2 \times 10^{3}$ & 3.51 \\
Ekciti market & $1.02 \times 10^{4}$ & 4.01 & $1.38 \times 10^{4}$ & 4.01 & $4.7 \times 10^{3}$ & 3.67 \\
Mile one market & $1.39 \times 10^{4}$ & 4.14 & $6.9 \times 10^{3}$ & 3.83 & $3.7 \times 10^{3}$ & 3.56 \\
New market & $3.16 \times 10^{4}$ & 4.49 & $3.0 \times 10^{3}$ & 3.47 & $3.1 \times 10^{3}$ & 3.49 \\
Branded samples & Nil & Nil & Nil & Nil & - & - \\
\hline
\end{tabular}

Table 2: Total heterotrophic mean fungal count

\begin{tabular}{lllllll}
\hline \multirow{2}{*}{ Markets } & \multicolumn{2}{l}{ Shea butter } & \multicolumn{2}{l}{ Coconut oil } & \multicolumn{2}{l}{ Palm kernel } \\
\cline { 2 - 7 } & Cfu/ml & Logcfu/ml & Cfu/ml & Logcfu/ml & Cfu/ml & Logcfu/ml \\
\hline Oba market & $1.02 \times 10^{1}$ & 2.00 & $3.0 \times 10^{2}$ & 2.47 & $5.5 \times 10^{3}$ & 3.74 \\
Ekiti market & $6.4 \times 10^{3}$ & 3.81 & Nil & Nil & Nil & Nil \\
Mile one market & $4.0 \times 10^{2}$ & 2.60 & $6.0 \times 10^{2}$ & 2.78 & $6.4 \times 10^{3}$ & 3.81 \\
New market & $1.4 \times 10^{3}$ & 3.15 & Nil & Nil & Nil & Nil \\
Branded samples & Nil & Nil & Nil & Nil & Nil & Nil \\
\hline
\end{tabular}

Table: 3 Antibiogram of Bacteria and frequency of occurrence of isolates obtained from edible oil samples

\begin{tabular}{|c|c|c|c|c|c|c|c|c|c|}
\hline \multicolumn{10}{|c|}{ Antibiotics } \\
\hline Isolates (Gram +$)$ & OFL & AUG & CAZ & CPX & GEN & CTR & ERY & $\mathrm{CXC}$ & Sensitivity (\%) \\
\hline Baccillus sp. (19\%) & $\mathrm{R}$ & $\mathrm{R}$ & $\mathrm{R}$ & $\mathrm{R}$ & $\mathrm{R}$ & $\mathrm{R}$ & $\mathrm{s}$ & $\mathrm{R}$ & 12.5 \\
\hline Baccillus sp. & $\mathrm{S}$ & $\mathrm{S}$ & $\mathrm{R}$ & $\mathrm{s}$ & $\mathrm{s}$ & $\mathrm{s}$ & $\mathrm{S}$ & $\mathrm{R}$ & 75 \\
\hline Staphyloccus sp. (29\%) & $\mathrm{s}$ & $\mathrm{s}$ & $\mathrm{R}$ & $\mathrm{s}$ & $\mathrm{R}$ & $\mathrm{s}$ & $\mathrm{S}$ & $\mathrm{R}$ & 62.6 \\
\hline Staphyloccus sp. & $\mathrm{s}$ & $\mathrm{R}$ & $\mathrm{R}$ & I & I & $\mathrm{R}$ & $\mathrm{s}$ & $\mathrm{R}$ & 25 \\
\hline Micrococcus sp. $(9 \%)$ & S & $\mathrm{S}$ & $\mathrm{R}$ & $\mathrm{R}$ & S & $\mathrm{R}$ & $\mathrm{S}$ & $\mathrm{R}$ & 50 \\
\hline Resistance (\%) & 20 & 40 & 100 & 40 & 40 & 60 & 0 & 100 & \\
\hline \multicolumn{10}{|c|}{ Antibiotics } \\
\hline Isolates (Gram -) & OFL & AUG & NIT & CPR & CAZ & $\mathrm{CRX}$ & GEN & $\mathrm{CXM}$ & Sensitivity (\%) \\
\hline Psedomonas sp. ( $(9 \%)$ & $\mathrm{s}$ & $\mathrm{R}$ & $\mathrm{R}$ & $\mathrm{s}$ & $\mathrm{R}$ & $\mathrm{R}$ & $\mathrm{R}$ & & 25 \\
\hline Escherichia coli (14\%) & S & S & S & S & $\mathrm{R}$ & S & S & $\mathrm{R}$ & 75 \\
\hline Klebsiella sp. (10) & $\mathrm{s}$ & $\mathrm{R}$ & $\mathrm{R}$ & $\mathrm{s}$ & $\mathrm{R}$ & $\mathrm{s}$ & I & $\mathrm{R}$ & 37.5 \\
\hline Enterbacter sp. $(10 \%)$ & $\mathrm{S}$ & $\mathrm{R}$ & $\mathrm{R}$ & $\mathrm{s}$ & $\mathrm{R}$ & $\mathrm{R}$ & $\mathrm{R}$ & $\mathrm{R}$ & 25 \\
\hline Resistance $(\%)$ & 0 & 75 & 75 & 0 & 100 & 50 & 50 & 100 & \\
\hline
\end{tabular}

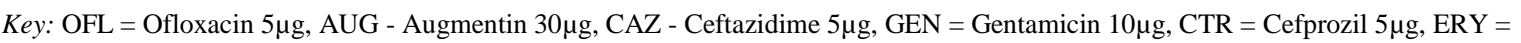

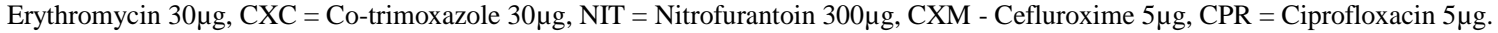
$\mathrm{S}=$ Sensitive, I= Intermediate, $\mathrm{R}=$ Resistance.

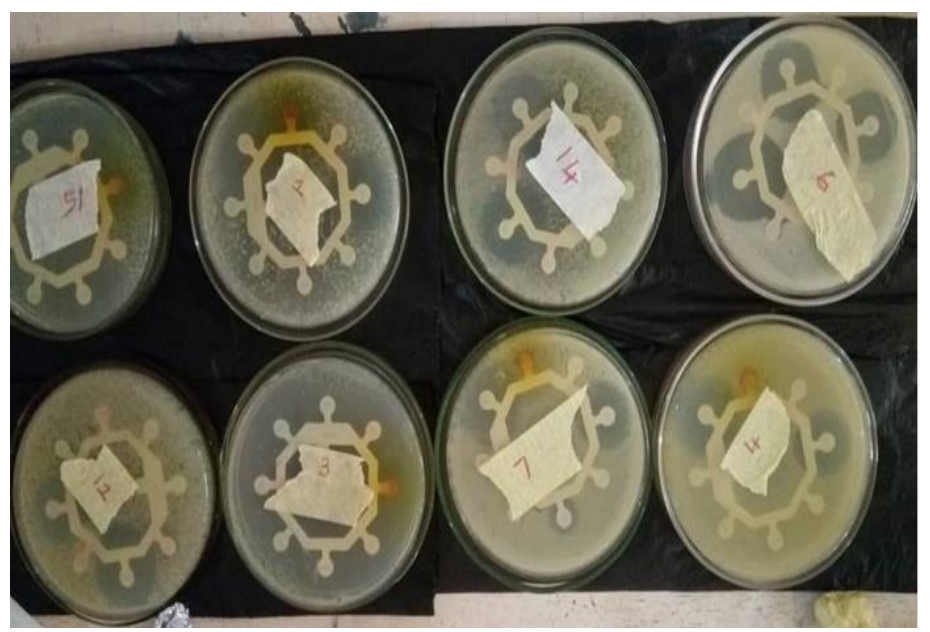

Plate 1: Antibiotic sensitivity of the isolated organism to the antibiotics

The bacteria isolated and identified from the samples were Bacillus sp, Escherichia sp, Pseudomonas sp, Micrococcus, Staphylococcus sp, Enterobacter sp, and klebsiella sp. These organisms are similar to those reported by Akomah-Abadaike and Sulaiman, (2019); Bukola and Onilude, (2017); Okechalu et al., (2011) and Lideya et al., (2018). Among the bacterial contamination, Staphylococcus sp had the highest frequency (29\%) of occurrence then Bacillus sp (19\%) while Micrococcus sp and Pseudomonas sp were the least occurring isolates. Some of the isolated 
organisms are pathogenic and cause diseases (Okechalu et al., 2011).

The findings of this study showed the total heterotrophic fungi count of the 12 unbranded edible oil and the 2 branded sample of vegetable ranged from $1.0 \times 10^{2} \mathrm{cfu} / \mathrm{ml}$ to $6.4 \times 10^{3} \mathrm{cfu} / \mathrm{ml}$ for all the unbranded samples. The fungi count of this study is similar to the report of Lideya et al., (2015) were he recorded fungi growth of 4.43 to $12.45 \times 10^{3} \mathrm{cfu} / \mathrm{ml}$, There was no growth of fungi for the branded samples of coconut oil and Shea butter. The highest count of fungi was recorded in Palm kernel oil from mile one market (MPK) while the least growth count of fungi was recorded in Shea butter from Oba market sample (OSB). Palm kernel oil sample from Ekitiafor market and coconut sample from new market also did not also produce count of fungi. The branded samples show no growth counts on all the media uses.

The antibiogram of Gram's positive bacteria revealed that all organisms were sensitive to Erythromycin (100\%). Ceftazidine and Co-trimoxazole have 100\% resistance (table 2). A combination of all available antibiotic show that Bacillus sp has the highest antibiotic resistance (87 5\%). The antibiogram of Gram's negative bacteria had all organisms sensitive to Ofloxacin and Ciprofloxacin (100\%). Ceftazidine and cefluroxime show $100 \%$ resistance by all organisms. A combination of the antibiotics shows that both Pseudomonas sp. and Enterbacter sp have the highest antibiotic resistance of $75 \%$.

Conclusion: The isolated microorganisms in this study include pathogenic bacteria and indicator organisms. All Grams' positive organisms isolated are sensitive to Erythromycin and all Grams' negative isolates are sensitive to Ofloxacin and Ciprofloxacin. NAFDAC and other regulatory agencies should be put more effort in regulating the quality of the edible oil to ensure healthy consumption of oil. Hazard analysis and critical control points (HACCP) should be observed in every stage in the production of the edible oil to reduce contamination especially for the unbranded samples of edible oil.

Acknowledgement: We are grateful to Austino Research \& Analysis Laboratory NIG. LTD. and Emadavistic Medical\& Research Laboratory for accurately analyzing our samples

\section{REFERENCES}

Afolabi Israel S. (2008). Chemical qualities of oils from some fresh and market vegetable crops within Kwara State, Nigeria. J. Nig. Soc. Experimental Bio. 20(2):7175 .
Akomah-Abadaike O.N and Sulaiman M.D (2019) Microbial Profiling and Antifungal Screening of Shea butter, Coconut oil and Palm kernel oil Sold in Port Harcourt Metropolis, Nigeria, Intern. J. Health, Safety. Environ. 5:409 - 414,

Bukola M. P and Omilude (A.A. 2017). Microorganism Associated with edible oil polluted soil. Adv. Microbiol. 7:377-386.

Cheesbrough, M. (2005).District Laboratory Practice in Tropical Countries. Part 1 (2nd ed), Cambridge University Press, U. K.

Chabiri, S.A., Hati, SS; Dimari, G.A. and Ogugbuaja, V.O.(2009). Comparative Quality Assessment of Branded and Unbranded Edible Edible oils in Nigeria. Pac. J. Sci. Technol. 10(2), 927934

Codex Alimentarius Commission (2009) Codex standard for named edible oils - "Codex Stan 210-1999" Food and Agricultural Organization of the United Nations and the World Health Organization. Sci. Technol. 10(2):927934.

Ezediokpu M. N., Omorodion N., Okerentugba P. O., Ego C. C. (2015). Quality Assessment of unbranded refined palm kernel oil in distribution within five local markets in Port Harcourt, Rivers state Nigeria. J. Agric. Vet. Sci. $8: 45-50$.

Gopala K. A., Gaurav R., Ajit S. B., Prasath K. P. and Precti C. (2010). Coconut oil: Chemistry, Production and its Application. Indian coconut J. 4:15-23.

Kenan D. and Ideli L. (2012). Determination of polycyclic aromatic hydrocarbon in edible oil and barbecued food by HPLC/UV-VIS detection. J. Food Chem. 133:193199.

Macaire, WH, Tienchen B., Tengyang W; Tchonanyuep, ME, Kapseu C., Linder M and Fanni.J. (2010). Extraction of Palm kernel oil in Cameroon: Effects of Kernel drying on the Oil quality. J. Foods Technol. $8(1): 1-7$

Mercy B., A. M. Johannes A. (2017). Determination of the triacylglycerol content for the identification and assessment of purity of shea butter fat, peanut oil and palm kernel oil using Maldi-tot/tof mass spectroscopic technique. J. Food Properties, 20(2):271-280.

MOH. (2012). Manual of analysis of oils and fats. Food safety ad standards authority of India, New Delhi. 24 27.

Okechalu J.N., Dashen M.M., Lar P.M., Okechalu B., Gushop T. (2011). Microbiological quality and Chemical Characteristics of Palm Oil sold in Jos Metropolis, Plateau State, Nigeria. J. Microbial Techenol. Res. 1(2):107-112. 